\title{
Skill-biased technical change: On technology and wages in the Netherlands
}

Citation for published version (APA):

Bruinshoofd, W. A., \& ter Weel, B. J. (1998). Skill-biased technical change: On technology and wages in the Netherlands. MERIT, Maastricht Economic Research Institute on Innovation and Technology. MERIT Research Memoranda No. 021 https://doi.org/10.26481/umamer.1998021

Document status and date:

Published: 01/01/1998

DOI:

10.26481/umamer.1998021

Document Version:

Publisher's PDF, also known as Version of record

\section{Please check the document version of this publication:}

- A submitted manuscript is the version of the article upon submission and before peer-review. There can be important differences between the submitted version and the official published version of record.

People interested in the research are advised to contact the author for the final version of the publication, or visit the DOI to the publisher's website.

- The final author version and the galley proof are versions of the publication after peer review.

- The final published version features the final layout of the paper including the volume, issue and page numbers.

Link to publication

\footnotetext{
General rights rights.

- You may freely distribute the URL identifying the publication in the public portal. please follow below link for the End User Agreement:

www.umlib.nl/taverne-license

Take down policy

If you believe that this document breaches copyright please contact us at:

repository@maastrichtuniversity.nl

providing details and we will investigate your claim.
}

Copyright and moral rights for the publications made accessible in the public portal are retained by the authors and/or other copyright owners and it is a condition of accessing publications that users recognise and abide by the legal requirements associated with these

- Users may download and print one copy of any publication from the public portal for the purpose of private study or research.

- You may not further distribute the material or use it for any profit-making activity or commercial gain

If the publication is distributed under the terms of Article $25 \mathrm{fa}$ of the Dutch Copyright Act, indicated by the "Taverne" license above, 


\title{
Skill-biased technical change:
}

\section{On technology and wages in the Netherlands}

\author{
Allard Bruinshoofd ${ }^{\mathrm{a}}$, Bas Ter Weel ${ }^{\mathrm{b}, *}$ \\ ${ }^{a}$ Research Centre for Education and the Labour Market (ROA) and Department of Economics, \\ Maastricht University, Maastricht, the Netherlands \\ ${ }^{b}$ Maastricht Economic Research Institute on Innovation and Technology (MERIT), \\ Maastricht University, Maastricht, the Netherlands
}

\begin{abstract}
This paper investigates the shift in demand away from low-skilled and towards high-skilled labour in the Netherlands over the 1990s. Making the distinction between the effects of technical change on job type and job level, the conclusion is that skill-biased technical change based on job level is the chief cause for this shift.
\end{abstract}

JEL Classification: J31; H52; O30

Keywords: Wage differentials; Inequality; Skill-biased technical change

* Corresponding Author. MERIT, P.O. Box 616, 6200 MD, Maastricht, the Netherlands; Tel: 0031-433883873; Fax: 0031-43-3216518; E-mail: b.terweel@ merit.unimaas.nl.

Useful comments from Hugo Hollanders and Luc Soete are gratefully acknowledged. 


\section{Introduction}

Technical change has significantly altered the demand for labour in OECD countries in the 1990s. Many tasks once carried out by low-skilled labour are now performed by automated equipment, thereby reducing the demand for low-skilled labour. At the same time the demand for high-skilled labour has increased substantially as a result of an accelerating stream of process innovations, e.g. the rapid evolution and wide applicability of information and communication technologies has made many tasks and jobs obsolete. Only recently, this notion of skill-biased technical change has gained pretentious attention both at the side of scholars in the field and policy makers because of its perturbing effects on the wage distribution and, as a consequence, inequality. Economists have started to develop models that are able to explain the rise in wage divergence which is a major measure of increasing inequality - cf. Heckman, Lochner and Taber (1998). On the side of policy makers the OECD has put effort in the analysis of the evolution of skills and the role of technical change - cf. Colecchia and Papaconstantinou (1996) and OECD (1996).

Why has this happened and what are the consequences? The answer to the first question is that the kind of technical change in the last decades requires relatively many high-skilled workers. It suggests that firms are increasingly prepared to pay for higher skilled workers as the costs associated with the tangible part of new investments have decreased with time - cf. Petit and Soete (1998). Moreover, employers have replaced increasingly expensive, low-skilled workers by relatively inexpensive high-skilled workers. This indicates that the returns to investment in high-level education has increased and has been accompanied by a major upskilling of the labour 
force, thereby polarising the wage distribution in most OECD countries. Typically, all sectors retained or increased the share of high-skilled workers, while decreasing the number of lowskilled workers they employ - cf. Muysken and Ter Weel (1998). ${ }^{1}$ In addition, it has been argued, by e.g. Autor, Katz and Krueger (1997) and Berman, Bound and Griliches (1994), that highskilled workers adapt more easily to changing technologies than their low-skilled colleagues.

While the evidence to date certainly suggests that technical change in the last decade in OECD countries has been skill biased, there are still very few microeconomic studies that directly examine how the wage distribution in the several sectors in the economy have been influenced by the adoption and use of new technologies. This paper aims to extend this literature by estimating wage equations for the Netherlands in 1992 and 1996. Following Doms, Dunne and Troske (1997) our analysis is twofold. First, using a cross-sectional data set that contains detailed information on worker characteristics, we address the following question with regard to a possible sector bias in skill-biased technical change: Do technologically advanced sectors pay white-collar workers like managers, scientists and engineers a higher wage relative to blue-collar workers than white-collar workers in less-advanced sectors? This exercise is carried out to build a distinctly and sharply outlined representation of a test for skill bias based on the type of job in the different sectors. Second, using the same cross-sectional data set we address the following question with respect to level bias in skill-biased technical change: Do technologically advanced sectors pay high-skilled workers a higher wage relative to low-skilled workers than

\footnotetext{
${ }^{1}$ The overall contention is that there may be numerous reasons for skill bias. It is not always directly linked to the nature of technical progress but can be due to some concurrent phenomena. Systematically opting for higher skilled workers can be a way for firms to face uncertainty. Furthermore, the development of trade with low-wage countries, although difficult to separate from technical change, contributes to some skill bias. This is due to further specialisation of Western economies into the production of high-tech goods and services requiring high-skilled labour and advanced technologies.
} 
technologically less-advanced sectors? The objective of this second question is to provide a more comprehensive picture of the relationship between workforce characteristics, technology and job level at the sector level.

The data we utilize come from two sources. The information on the technological advancement of sectors is based on R\&D intensities which can be adapted from the OECD's STAN Database. We define $R \& D$ intensity as the sum of all $R \& D$ expenditures in a particular sector divided by the value added of this sector. Following the neoclassical tradition we use the resulting R\&D variable as an input variable in the production function and in our regression model. The information on worker characteristics comes from the OSA database which is a panel data set. We use both the 1992 and 1996 database.

Our cross-sectional results are consistent with the view that sectors with high R\&D intensities pay white-collar workers relative to blue-collar workers in the same sector a higher wage than white-collar workers in other sectors. This positive correlation between the R\&D intensity of a sector and the relative wage rate of white-collar workers is found to be increasing over the 1990s. Hence, our contention of a sector bias in skill-biased technical change is confirmed and strengthened over the 1990s. Likewise, we find that the wage rate of high-skilled workers relative to low-skilled workers increases with the degree of R\&D intensity. In addition, this correlation is increasing strongly from 1992 to 1996 . Thus, our second statement in support of the argument of skill-biased technical change is also established: Wage divergence is stronger in technologically advanced sectors relative to technologically less-advanced sectors. 
In the remainder of this paper we first give an overview on the growing empirical literature with regard to technical change and wages. Secondly, we estimate, using the OSA database, wage equations for the Netherlands in 1992 and 1996. We end with some concluding remarks. 


\section{Background}

In the econometric literature on the impact of technical change on employment, much evidence has been brought together highlighting the reduction of the demand for low-skilled labour relative to the demand for high-skilled labour. This skill bias can be explained by various factors. For instance, in Griliches (1969) it is due to the relative decline of the price of capital, while Denny and Fuss (1983) attribute the skill bias to the specific effects of technical change. Murphy, Riddell and Romer (1998) conclude that new technologies are relative complements with more educated labour which is closely related to the thesis that machinery and new technologies harm low-skilled workers. In general the rationale for the argument put forward is that high-skilled workers and capital are complements, whereas high-skilled labour and low-skilled labour are substitutes, e.g. many routine assembly activities can be replaced - cf. Goldin and Katz (1998) for a recent overview.

Table 1 The changing education structure of KPN Telecom

\begin{tabular}{lrrrrrr}
\hline Education & 1990 & 1991 & 1992 & 1993 & 1994 & $\% \Delta$ \\
\hline Primary & 2.083 & 1.181 & 867 & 1.134 & 1.463 & -29.8 \\
Primary professional & 7.135 & 7.599 & 7.100 & 6.017 & 5.296 & -25.8 \\
Secondary & 6.654 & 7.320 & 7.558 & 4.949 & 4.350 & -34.6 \\
Secondary professional & 10.930 & 12.171 & 12.820 & 16.088 & 16.475 & 50.7 \\
Higher professional & 3.180 & 3.882 & 4.216 & 4.124 & 4.264 & 34.9 \\
University degree & 1.115 & 1.502 & 1.565 & 1.369 & 1.487 & 33.4 \\
\hline Total & 31.097 & 33.655 & 34.126 & 33.681 & 33.335 & 7.2 \\
\hline
\end{tabular}


This shedding of unskilled labour at the sectoral level has occurred in most OECD countries in the last decade. Table 1 indicates how the qualifications profile of the workforce has shifted in favour of groups with greater educational qualifications. We use a Dutch high-tech service company - KPN Telecom - as an example. From this table it is clear that in a relatively short period of time (1990-1994) the workforce at KPN Telecom has changed in a dramatic fashion. Individuals with an educational level ranging from primary to secondary saw their employment level fall by more than thirty percent, while individuals with an educational level from secondary professional on observed an employment increase ranging from $33.4 \%$ for individuals with an university degree to an increase of $50.7 \%$ for employees at the secondary professional level.

At the same time, the shedding of unskilled labour has also consequences for employment at the macroeconomic level. Table 2 shows evidence for the Netherlands that the least educated persons face higher unemployment rates than their higher educated colleagues. From the table it is also clear that this is an increasing trend throughout the 1990s.

Table 2 Unemployment by educational attainment for persons aged 25-64

\begin{tabular}{rrrr}
\hline & $\begin{array}{r}\text { Less than upper } \\
\text { secondary education }\end{array}$ & Upper secondary & Tertiary level \\
education & education \\
\hline 1992 & 9 & 5 & 5 \\
1993 & 11 & 6 & 5 \\
1994 & 12 & 7 & 6 \\
1995 & 12 & 7 & 6 \\
1996 & 13 & 6 & 5 \\
\hline
\end{tabular}

Source: OECD (1997a), (1998b) 
The debate on the wage premium due to new technologies at the individual level has been initiated by an influential study of Krueger (1993), but the evidence from several studies is not conclusive. Krueger shows that in the US the use of computers brought the workers surveyed a wage premium of some $15 \%$. Such a premium could be attributed either to an increase in productivity or to user's personal characteristics, which led them in all cases to receive significantly higher wages. Krueger favours the first explanation, even though cross-section data did not allow for such conclusions to be drawn. By contrast, Entorf and Kramarz (1995) show for France that workers using computers did already receive a higher wage before they started using one. Moreover, Di Nardo and Pischke (1997) - in a critical assessment of Krueger's results - observe for Germany that the use of pencils has a similar effect on the wage rate as computer use has. Only Bell (1996), using a sample of one thousand individuals finds a net increasing effect on wages for those using computers at work. Other empirical studies carried out by e.g. Baldwin, Divery and Johnson (1995) for Canada, Bellman and Boeri (1995) for Germany, Laaksonen and Vainiomaki (1995) for Finland, Entorf and Kramarz (1995) for France, Chennells and Van Reenen (1994) and Hildreth (1995) for the UK and Doms, Dunne and Troske (1997) for the US find similar results when examining the technology wage premium; these observations are summarized in Table $3 .^{2}$

\footnotetext{
${ }^{2}$ See also e.g. Bartel and Sicherman (1995), Bound and Johnson (1992), Heckman, Lochner and Taber (1998), Heckman and Sedlacek (1985), Katz and Murphy (1992), Meghir and Whitehouse (1996) and Nickell and Bell (1995).
} 
Table 3 Summary of papers on technology and wages

\begin{tabular}{|c|c|c|c|c|}
\hline Country & Authors & Technology measure & Worker data & Results \\
\hline Canada & Baldwin, Diverty and Johnson (1995) & Manufacturing technologies & Mean income per worker & $\begin{array}{l}\text { Technology wage premium } 10-30 \% \\
\text { depending on category }\end{array}$ \\
\hline Germany & Bellman and Boeri (1995) & Relative technology status & Proportion qualified workers & Technology wage premium up to $16.6 \%$ \\
\hline Finland & Laaksonen and Vainiomaki (1995) & Industry level technology & (Non)-manual workers & $\begin{array}{l}\text { Lowest technology industry pays lowest } \\
\text { wages }\end{array}$ \\
\hline France & Entorf and Kramarz (1995) & Specific technology use among workers & Worker characteristics & $\begin{array}{l}\text { Up to } 4 \% \text {, initially, and } 1 \% \text { per year of } \\
\text { experience }\end{array}$ \\
\hline \multirow[t]{2}{*}{ UK } & Chennels and Van Reenen (1995) & Introduction of new technologies & Three worker categories & Wage premium ranged from $1-6 \%$ \\
\hline & Hildreth (1995) & Product and process innovation & Worker data & $\begin{array}{l}\text { New process technologies lead to higher } \\
\text { worker wages }\end{array}$ \\
\hline US & Krueger (1993) & Computer use & Worker data & Up to a $15 \%$ wage premium \\
\hline & Doms, Dunne and Troske (1997) & Technology indicators for manufacturing & Worker data & Technology wage premium from $6-15 \%$ \\
\hline
\end{tabular}

Source: OECD (1996) 
The studies in the table above mainly use manufacturing data for their estimates. Hence, it is difficult to sketch a clear-cut overall picture of the economy from manufacturing data only. The chief reason for this is that comprehensive data are only available for manufacturing. Most of the direct evidence on the relationship between worker skills and technology is therefore based on data samples covering only a small part of the economy. These data limitations also play a role in the technology measures. Technology indicators range from computer use to some vague concept whether or not workers use 'specific' advanced technologies or not. Therefore, evidence is difficult to come by because of a lack of data sets with information on both technologies and worker skills. Only Doms, Dunne and Troske (1997) have reliable data on technology. The information on technology use and adoption in their paper comes from the 1988 and 1993 Survey of Manufacturing Technology. These surveys asked a sample of manufacturing plants about their use and adoption of new factory automation equipment.

Recent work by the OECD (1996) to construct some comprehensive and relatively easy to handle measures for the advancement of technologies in certain sectors has resulted in the use of R\&D intensities as a measure of technology. Using new data on employment by industry and occupations they have tried to test the hypothesis that the change in the skill composition in each manufacturing industry will follow the general upskilling trend in manufacturing with some deviations from it. Overall the increase in the share of white-collar high-skilled workers within sectors seems to be positively correlated to variables related to technical change, such as $R \& D$ intensities and growth in the number of patents; this is particularly observed for sectors employing a relatively large proportion of high-skilled labour (OECD, 1996, p. 97). Moreover, the results show in effect a strong positive correlation between the increasing share in high- 
skilled and mostly white-collar workers and initial R\&D intensity. Hence, industries with traditionally high $R \& D$ intensities have observed a relative large inflow of high-skilled and white-collar workers.

Table 4 R\&D Intensities in the Netherlands 1975-1994

\begin{tabular}{|c|c|c|c|c|c|c|}
\hline Sector & ISIC & 1975 & 1980 & 1985 & 1990 & 1994 \\
\hline Food, drink and tobacco & 31 & 0.0181 & 0.0221 & 0.0203 & 0.0192 & 0.0218 \\
\hline Textiles, footwear, leather & 32 & 0.0043 & 0.0031 & 0.0056 & 0.0075 & 0.0087 \\
\hline Wood, cork and furniture & 33 & 0.0022 & 0.0002 & 0.0005 & 0.0008 & 0.0009 \\
\hline Paper and printing & 34 & 0.0018 & 0.0018 & 0.0017 & 0.0024 & 0.0025 \\
\hline Chemical industry & 35 & 0.0754 & 0.0812 & 0.0803 & 0.0827 & 0.0685 \\
\hline Stone, clay and glass & 36 & 0.0045 & 0.0040 & 0.0049 & 0.0045 & 0.0065 \\
\hline Basic metals & 37 & 0.0283 & 0.0205 & 0.0178 & 0.0241 & 0.0548 \\
\hline Metal products & 38 & 0.0688 & 0.0738 & 0.1024 & 0.0856 & 0.0798 \\
\hline Electricity, gas and water & 4 & 0.0016 & 0.0016 & 0.0016 & 0.0019 & 0.0011 \\
\hline Construction & 5 & 0.0015 & 0.0014 & 0.0015 & 0.0011 & $0.0009^{*}$ \\
\hline Other Services & $6,7,8,9$ & 0.0011 & 0.0011 & 0.0013 & 0.0014 & $0.0018^{*}$ \\
\hline Total manufacturing & & 0.0453 & 0.0481 & 0.0592 & 0.0541 & 0.0494 \\
\hline Total services & & 0.0012 & 0.0012 & 0.0013 & 0.0014 & 0.0021 \\
\hline Agriculture & & 0.0039 & 0.0031 & 0.0029 & 0.0041 & 0.0100 \\
\hline Total & & 0.0131 & 0.0118 & 0.0139 & 0.0121 & 0.0124 \\
\hline
\end{tabular}

* 1993

Source: STAN database

Table 4 provides an overview of the R\&D intensities - which are defined as R\&D expenditures over value added - for several sectors for 1975, 1980, 1985, 1990 and 1994. From this table we 
observe that the manufacturing sector spends about five percent of its value added on $R \& D$ whereas the service sector spends not even one percent of its total value added on R\&D activities. Within manufacturing the chemical and metal sectors put most effort in R\&D: between 5 and $8 \%$ in 1994. In our estimation procedure we take into account the effort put in R\&D activities to investigate whether or not these innovative activities result in a relatively higher wage for both white-collar (relative to blue-collar) and high-skilled labour (relative to low-skilled). To do so, we label the three sectors with $R \& D$ intensities above the average $R \& D$ intensity in manufacturing $R \& D$ intensive. These sectors are chemicals industry, basic metals and metal products, which is in line with the labels of the European Commission's science and technology report (European Union, 1997). In this report the pharmaceutical (ISIC 3522), aerospace (ISIC 3845), computers and office machinery (ISIC 3825), electronics (ISIC 383), instruments (ISIC 385), chemicals (ISIC 35), motor vehicles (ISIC 3843) and electrical machinery (ISIC 383-3832) are labelled R\&D intensive. We add to this the basic metals sector (ISIC 37) containing ferrous and non-ferrous metal products. The reason for high $R \& D$ intensities in these sectors is the presence of $e . g$. Hoogovens and Budelco in this sector; these two firms have recently invested huge sums of money in innovative activities. Hoogovens is included in the ferrous metal products sector, while Budelco is present in the non-ferrous metal sector.

Before we start our empirical analysis we start with a short description of our databases. 


\section{Data}

The term 'skill' cannot be caught in a simple straightforward definition. The OECD defines it as "the qualifications needed to perform certain tasks in the labour market" (OECD, 1996, p. 82). In the most general sense, it reflects the level of human capital in the labour market, and upskilling can be seen as synonymous with human capital development. Wolff (1995) agrees with this definition but adds that 'skill' is a multi-dimensional concept, since most jobs require a multitude of skills for adequate task performance, ranging from physical abilities like eye-hand coordination, dexterity and strength, to cognitive skills - like analytic and synthetic reasoning. numerical and verbal abilities - and interpersonal - like supervisory, leadership - skills. We define four different skills. First, we make a distinction between blue-collar and white-collar workers based on the definitions used in the OSA database. Secondly, we categorize some occupations as high-skilled and others as low-skilled occupations.

Empirical studies often use proxies based on education and occupation. Education is categorised by years of schooling or final degree obtained. Occupations sometimes provide more information on the skills requirement for workers because it also takes into account on-the-job training and experience. For the present paper we use OSA-supply-surveys for the Netherlands. These surveys are conducted by the Organisation for Strategic Labour market research. The empirical results presented in the next section are based on the fifth (2406 obsevrations) and seventh (2317 observations) waves of the OSA labour supply panel. The first wave stems from 1985. Later surveys were conducted every two years (1986, 1988, 1990, 1992, 1994, 1996). The survey contains data on wages, education, occupation and personal characteristics like gender and 
nationality of individuals that are part of the potential labour force of age 16-65. An attempt is made to survey the same individuals in consecutive surveys. Dropouts are replaced by new observations.

Since we also want to determine which sectors within the Dutch economy can be defined as advanced sectors we use $R \& D$ data to determine the level of technical change within these sectors. We use the OECD's STAN database, which is an estimated database that reflects general trends over time and that captures the relative relationships that prevail between industries. ${ }^{3}$ The source databases for STAN are ISIS - the OECD Industrial Structure Statistics database for 67 manufacturing industries in ISIC - UNIDO - the United Nations Industrial Development Organization - UNSO - the United Nations Statistical Office industrial survey database - Eurostat - the INDE and VISA annual industrial survey databases, collected under the NACE industrial classification - and COMTAP - a database consisting of Comparable Trade And Production, which is maintained by the OECD's Statistics Department. The estimation procedure of the STAN database consists of two parts. In the first, a series of least squares regressions is calculated between the primary source and each of the secondary sources, for each countryvariable-industry combination being estimated. This procedure is then repeated with other secondary sources until no estimation is possible anymore. The procedure uses only published data. We have output and R\&D data for the Netherlands from 1973 to 1994 . For convenience, we use only two-digit data from this database.

\footnotetext{
${ }^{3}$ For a detailed description of the STAN database and its creation we refer to OECD (1994).
} 


\section{Estimation and results}

In this section we report the results from our cross-sectional analysis on technology, worker skills and wages. We take a more or less neoclassical position to show that the Netherlands observe skill-biased technical change in the second half of the 1990s. To start with, we assume that technical change is the outcome of a production function in which the input of R\&D is an expenditure. Then we assume that wages are an accurate measure for a worker's marginal product - following e.g. Krueger (1993). To do so we perform OLS tests on our data to investigate whether we observe wage divergence or dispersion in 1992 and 1996. In addition, we will investigate whether wage divergence has increased over the 1990s. The main objective is to carefully make a distinction between the sector bias component in skill-biased technical change and the job level measure. In this manner we can distinctly and sharply judge whether in some sectors wage divergence is due to the type of job an individual performs (i.e. white-collar versus blue-collar) or whether wage divergence is a consequence of job levels (i.e. high-skilled versus low-skilled jobs). To do so, we first construct the following standard wage equation:

$$
\ln \text { WHOUR }_{i}=\alpha_{i}+A G E_{i}+D_{i}^{\text {WBEAA }}+D_{i}^{\text {GENDER }}+E D U C_{i}+\text { LEVEL }_{i}+\sum_{0}^{j} D_{j, i}^{S E C T O R}
$$

where $\ln W H O U R_{i}$ is defined as the $\log$ of the hourly wage individual $i$ earns, $D_{i}^{\text {WBEAA }}$ is a dummy variable including individuals originally from Surinam, the Dutch Antils, Aruba, Turkey and Morocco $^{4}, E D U C_{i}$ and $L E V E L_{i}$ are defined as type and level of education individual $i$ has

\footnotetext{
${ }^{4}$ who have been designated as workers with particularly meager labour market perspectives by the Dutch Ministry of Social Affairs and Employment.
} 
attained, respectively. Finally, we have included $\mathrm{j}$ sector dummies, $D_{j, i}^{\text {SECTOR }}$, to analyse the influence of being employed in a certain sector on individual $i$ 's hourly wage. ${ }^{5}$

The OLS estimation of equation (1) for 1992 gives us the following results. First, we observe for the data set as a whole a relative high degree of wage discrimination $(33.1 \%)$ in favour of male workers, whereas discrimination with regard to race does not seem to be present. In 1996 wage discrimination based on gender has almost disappeared ( $2 \%$ in favour of males), while discrimination based on race has increased from 1992 to 1996 but the coefficient $(-0.033)$ is still statistically insignificant. In addition, we can conclude from Table 5 that the level of the job has no significant impact in 1992 on an individual's wage, while in 1996 there is a positive influence of more than four percent.

Table 5 Benchmark test

\begin{tabular}{|c|c|c|}
\hline Variables & 1992 & 1996 \\
\hline Constant & $2.152(0.153)$ & $3.485(0.072)$ \\
\hline AGE & $0.052(0.008)$ & $0.061(0.017)$ \\
\hline GENDER & $-0.331(0.042)$ & $-0.020(0.004)$ \\
\hline EDUC & $0.073(0.022)$ & $0.056(0.011)$ \\
\hline LEVEL & $0.010(0.024)$ & $0.042(0.010)$ \\
\hline $\mathrm{D}^{\mathrm{WBEAA}}$ & $-0.019(0.230)$ & $-0.033(0.125)$ \\
\hline
\end{tabular}

Note: Standard errors in brackets

The returns to education are $7.3 \%$ in 1992 and 5.6\% in 1996 (Table 5) which is in line with findings of other studies. E.g. Cohn and Kahn (1995) find a return to education of 7.7\%; Groot

\footnotetext{
${ }^{5}$ Note: LEVEL $_{\mathrm{i}}$ (job level) is based on employer's perceptions subdivided into seven broad classes. In contrast, skill-level and worker collar are determined by the CBS occupational classification of 1992. The distinction between the two variables ameliorates the bias that emanates from over- or undereducation, which is not corrected for in our analysis.
} 
(1993) obtains a return of 5.3\%; Hartog and Jonker (1996) find returns ranging from 5.8 to 8.4 percent; Hartog and Oosterbeek (1988) observe returns for females to be 5.2\% and returns for males to be 7.6\%; Oosterbeek and Webbink (1996) estimate that the returns to education are 9.2\%; Rumberger (1986) finds results ranging from $4.1 \%$ to $10.9 \%$ depending on gender and type of education; and Sicherman (1991) obtains a result of $4.8 \%$.

Table 6 Benchmark test for sectors

\begin{tabular}{lrr}
\hline \multicolumn{1}{c}{ Variables } & \multicolumn{1}{c}{1992} & \multicolumn{1}{c}{1996} \\
\hline Basic Metals & $-0.144(0.089)$ & $-0.062(0.045)$ \\
Chemical industry & $-0.016(0.182)$ & $0.046(0.062)$ \\
Metal products & $-0.133(0.079)$ & $0.011(0.038)$ \\
& & \\
Agriculture & $-0.682(0.147)$ & $-0.021(0.073)$ \\
Food, drink and tobacco & $-0.189(0.113)$ & $0.045(0.059)$ \\
Electricity, gas and water & $-0.060(0.128)$ & $0.179(0.065)$ \\
Construction & $-0.848(0.077)$ & $-0.052(0.038)$ \\
Trade & $-0.197(0.066)$ & $-0.084(0.031)$ \\
Transport and communication & $0.024(0.080)$ & $0.045(0.039)$ \\
Other commercial services & $-0.327(0.064)$ & $-0.052(0.031)$ \\
Banking and insurances & $0.194(0.093)$ & $0.098(0.049)$ \\
Tertiary services & $-0.112(0.063)$ & $-0.098(0.029)$ \\
\hline
\end{tabular}

Note: Standard errors in brackets

In Table 6 we show the sector analysis for the twelve sectors in our database relative to the government sector. Particularly the results from the agricultural and construction sector in 1992 are somewhat surprising. These highly negative coefficients $(-0.570$ and -0.736 , respectively) could be due to the fact that many workers in these sectors are self-employed and do not earn a wage like ordinary employees do. Thus, for these workers profit equals income, but income does not equal wage. Indeed, when we have a closer look at the data for these two sectors we observe many 'zero' wages; the coefficients turn out to be more intuitively plausible in 1996 . The other 
sectors show a diverse pattern in 1992. Relative to the government sector only the transport and communication and banking sector observe higher wages, whereas the other sectors observe relatively lower wages. In 1996 the spread of the coefficients is larger than in 1992 and more coefficients are positive.

Table 7 Benchmark test for occupations

\begin{tabular}{|c|c|c|}
\hline Variables & 1992 & 1996 \\
\hline Elementary & $-0.190(0.095)$ & $0.051(0.046)$ \\
\hline Low & $-0.224(0.067)$ & $-0.101(0.033)$ \\
\hline Low adm./com. & $-0.359(0.071)$ & $-0.100(0.034)$ \\
\hline Medium & $-0.035(0.059)$ & $-0.061(0.029)$ \\
\hline \multicolumn{3}{|l|}{ Medium adm./com. } \\
\hline High & $0.171(0.089)$ & $0.075(0.039)$ \\
\hline High adm./com. & $0.161(0.081)$ & $0.082(0.037)$ \\
\hline Scientific & $0.155(0.148)$ & $0.052(0.064)$ \\
\hline Scientific eco./adm. & $0.193(0.125)$ & $0.159(0.052)$ \\
\hline
\end{tabular}

Note: Standard errors in brackets

In addition, we augmented regression equation (1) by adding a number of occupational dummies. In Table 7 we report the results of this occupations analysis. Although the results do not show a clear pattern, the high-low distinction relative to our reference point, a medium level administrative and/or commercial job, is clear. Note that administrative and/or commercial jobs in general obtain a higher wage. The only exceptions being the low-level and high-level administrative and/or commercial jobs in 1992.

If we now elaborate on Table 7 by not making the distinction between job levels (high-low) but between job types (white-blue-collar) thus adding an additional dummy variable to equation (1): 


$$
\begin{aligned}
& \ln \text { WHOUR }_{i}=\alpha_{i}+A G E_{i}+D_{i}^{\text {WBEAA }}+D_{i}^{\text {GENDER }}+\text { EDUC }_{i}+\text { LEVEL }_{i}+ \\
& \sum_{0}^{j} D_{j, i}^{\text {SECTOR }}+D_{i}^{\text {WHITECOLLAR }}
\end{aligned}
$$

we observe that in 1992 white-collar workers earn a $1.1 \%$ higher wage than their blue-collar colleagues. However, this coefficient is insignificant with a standard error of 0.037 . For 1996 the coefficient more than doubles $(2.7 \%)$ but is still insignificant. Hence, we do not find any statistically significant difference in wages between white-collar and blue-collar workers.

In Table 4 in section 2 we labelled three industries as innovative because of their high R\&D intensities (basic metals, chemical industry, and metal products) and our contention was that workers in these sectors would obtain a higher wage because of our general notion of skill-biased technical change. Therefore, we adapt equation (1) in the following way:

$$
\begin{gathered}
\ln \text { WHOUR }_{i}=\alpha_{i}+A G E_{i}+D_{i}^{\text {WBEAA }}+D_{i}^{\text {GENDER }}+\text { EDUC }_{i}+\text { LEVEL }_{i}+ \\
\sum_{0}^{j} D_{j, i}^{\text {SECTOR }}+\sum_{0, \ldots, l, l+1, \ldots}^{j} D_{i}^{\text {WHITECOLLAR }} \times D_{i, j}^{\text {SECTOR }}
\end{gathered}
$$

where the sectors from 0 to $l$ are R\&D intensive and the sectors from $l+l$ on are not. This way, 
we perform a sector analysis of white collar wage premia (Table 8) by including this white-collar dummy as an interaction variable with the sector dummies. However, we do not find comprehensive results for the economy as a whole. The coefficient for metal products in 1992 is positive but insignificant whereas the coefficients for the other two presumed innovative sectors are negative and insignificant, underlining that blue-collar and white-collar workers do not observe different wages. In 1996 we observe a large increase in wages in the basic metals sector and a fall in wages in the metal products sector.

Table 8 Testing for wage divergence between blue- and white-collar workers

\begin{tabular}{lrr}
\hline \multicolumn{1}{c}{ Sector } & \multicolumn{1}{c}{1992} & \multicolumn{1}{c}{1996} \\
\hline Basic Metals & $-0.030(0.191)$ & $0.232(0.108)$ \\
Chemical industry & $-0.182(0.266)$ & $-0.099(0.142)$ \\
Metal products & $0.311(0.169)$ & $0.127(0.083)$ \\
& & \\
Agriculture & $1.080(0.837)$ & $0.312(0.401)$ \\
Food, drink and tobacco & $0.171(0.357)$ & $-0.064(0.141)$ \\
Electricity, gas and water & $-0.419(0.284)$ & $-0.093(0.150)$ \\
Construction & $1.056(0.193)$ & $0.037(0.119)$ \\
Trade & $0.298(0.154)$ & $0.109(0.077)$ \\
Transport and communication & $0.127(0.187)$ & $0.063(0.097)$ \\
Other commercial services & $0.368(0.108)$ & $0.115(0.057)$ \\
Banking and insurances & $0.197(0.181)$ & $0.034(0.103)$ \\
Tertiary services & $0.119(0.098)$ & $-0.065(0.045)$ \\
\hline
\end{tabular}

Note: Standard errors in brackets

To see whether this pattern has statistical relevance, we extend equation (1) in the following manner:

$$
\ln W H O U R_{i}=\alpha_{i}+A G E_{i}+D_{i}^{W B E A A}+D_{i}^{G E N D E R}+E D U C_{i}+L_{i} V E L_{i}+
$$




$$
\sum_{0}^{j} D_{j, i}^{\text {SECTOR }}+D_{i}^{\text {WHITECOLLAR }} \times D_{i, j}^{\text {SECTOR }} \quad \text { for all } j \leq l
$$

The result for 1992 of equation (4) is a $6.8 \%$ wage premium for white-collar workers in the R\&D intensive sectors, ${ }^{6}$ with a standard error of $9.1 \%$, meaning that overall there is no significant evidence for wage divergence based on the job type / sector combination of an employee. For the remainder of this paper this will be labelled as white-collar sector bias. However, in 1996 the coefficient doubles to $14 \%$ and turns out to be highly significant. This means that over the 1990 s white-collar workers in R\&D intensive sectors have faced a much higher increase in wages than all other workers. Hence, our statement that there is a clear-cut white-collar sector bias in the general pattern of skill-biased technical change is valid.

Now that the wages of white-collar workers has been analysed, we turn our attention to the asymmetry in wage growth of high-skilled workers. The OSA data on occupation can be redefined in the two categories: low- and high-skilled jobs:

$$
\ln \text { WHOUR }_{i}=\alpha_{i}+A G E_{i}+D_{i}^{W B E A A}+D_{i}^{G E N D E R}+E D U C_{i}+L_{i} E E L_{i}+
$$




$$
\sum_{0}^{j} D_{j, i}^{\text {SECTOR }}+D_{i}^{H I G H-S K I L L E D}
$$

The result of equation (5) is not surprisingly that workers employed on a high-skilled job obtain a $12.8 \%$ (significant at a five percent level) higher wage in 1992 and a $10.8 \%$ (significant at a five percent level) higher wage in 1996 than individuals employed on a low-skilled job. If we investigate the sector specific evidence (presented in table 9) by means of equation (6).

$$
\begin{gathered}
\ln \text { WHOUR }_{i}=\alpha_{i}+A G E_{i}+D_{i}^{\text {WBEAA }}+D_{i}^{\text {GENDER }}+\text { EDUC } C_{i}+\text { LEVEL }_{i}+ \\
\sum_{0}^{j} D_{j, i}{ }_{0, \ldots, l, l+1, \ldots}^{\text {SECTOR }}{ }^{j} D_{i}^{H I G H-S K I L L E D} \times D_{i, j}^{\text {SECTOR }}
\end{gathered}
$$

Again we do not observe a direct indication for our thesis that high-skilled workers in the R\&D intensive sector obtain higher wages in 1992. This pattern is quite different in 1996. In 1996 the four R\&D intensive sectors all pay higher wages to high-skilled workers, whereas the coefficients in the other sectors are negative or at least insignificant. This is an early indication of a highskilled sector bias, meaning that high-skilled workers in high R\&D intensity sectors earn a wage premium over both the low skilled workers in general and their high-skilled colleagues in low $R \& D$ intensity sectors. 
Table 9 Testing for wage divergence between high and low-skilled jobs

\begin{tabular}{lrr}
\hline \multicolumn{1}{c}{ Sector } & 1992 & 1996 \\
\hline Basic Metals & $-0.034(0.158)$ & $0.159(0.084)$ \\
Chemical industry & $-0.228(0.244)$ & $0.049(0.124)$ \\
Metal products & $0.132(0.139)$ & $0.144(0.067)$ \\
& & \\
Agriculture & $0.665(0.495)$ & $0.463(0.402)$ \\
Food, drink and tobacco & $0.007(0.222)$ & $0.011(0.131)$ \\
Electricity, gas and water & $-0.260(0.247)$ & $0.000(0.124)$ \\
Construction & $0.959(0.150)$ & $0.143(0.079)$ \\
Trade & $-0.134(0.098)$ & $-0.033(0.046)$ \\
Transport and communication & $-0.230(0.136)$ & $-0.033(0.069)$ \\
Other commercial services & $-0.213(0.091)$ & $-0.061(0.048)$ \\
Banking and insurances & $0.310(0.303)$ & $-0.124(0.183)$ \\
Tertiary services & $-0.061(0.086)$ & $-0.020(0.040)$ \\
\hline
\end{tabular}

Note: Standard errors in brackets

This leaves us to compute the formal test for this high-skilled sector bias by means of equation (7).

$$
\begin{gathered}
\ln \text { WHOUR }_{i}=\alpha_{i}+A G E_{i}+D_{i}^{\text {WBEAA }_{i}+D_{i}^{\text {GENDER }}+\text { EDUC }_{i}+\text { LEVEL }_{i}+} \\
\sum_{0}^{j} D_{j, i}^{\text {SECTOR }}+D_{i}^{\text {HIGH-SKILLED }} \times D_{i, j}^{\text {SECTOR }} \text { for all } j \leq l
\end{gathered}
$$

We obtain in 1992 an insignificant coefficient of $2.2 \%$ for this sector bias which indicates that high-skilled workers in $R \& D$ intensive sectors do hardly observe higher wages than their colleagues in the other sectors. Again the observation in 1996 is different and in favour of our thesis. High-skilled workers in the R\&D intensive sectors earn a near $18 \%$ wage premium over their low-skilled colleagues and those employed in the technologically lagging sectors. 
In conclusion we can state that we do not observe any significant wage divergence in the Netherlands in 1992. Even if we perform special tests based on job type and job level the evidence is not convincing enough to be able to give suspicion for skill-biased technical change. In addition, the relative $R \& D$ intensive sectors do not give any reason to suspect an effect of R\&D on wages. However, the analysis of the 1996 data proves that we face skill-biased technical change in the Netherlands based on both job type and job level. The analysis shows that the position of both high-skilled workers and white-collar workers has significantly improved over the past half decade. Furthermore, we observe that skill-biased technical change is more important with regard to the job level of an individual than on the proper use of skills, i.e. the position of high-skilled workers improves more than the position of white-collar workers. 


\section{Concluding remarks}

In summary, our cross-sectional results are consistent with what other researchers in the field have found concerning the cross-sectional relationship between technology and wages with respect to skill-biased technical change. The positive correlation we have established between $\mathrm{R} \& \mathrm{D}$ intensity and the relative wage rate is confirmed, while we have added the distinction between skill-biased technical change based on job type and skill-biased technical change based on job level. Particularly the latter effect is strong and increasing over the 1990s. This is consistent with the thesis that low-skilled labour is obsolete in innovative sectors, which has already theoretically been underlined by e.g. Aghion and Howitt (1998) and Muysken and Ter Weel (1998). To conclude we can state that our results do imply that technical change does benefit high-skilled labour, whereas it deteriorates the position of low-skilled labour. 


\section{References}

Aghion, P. and P. Howitt, Endogenous Growth Theory (Cambridge Massachusetts: MIT Press).

Autor, D. H., L. F. Katz and A. B. Krueger, 1997, Computing inequality: have computers changed the labor market?, National Bureau of Economic Research, Working Paper No. 5956.

Baldwin, J. R., B. Diverty and J. Johnson, 1995, Success, innovation, technology and human resource strategies an interactive system, Paper presented at the conference on the effects of technology and innovation on firm performance and employment, Washington DC.

Bartel, A. and N. Sicherman, 1995, Technological change and the skill acquisition of young workers, National Bureau of Economic Research, Working Paper No. 5107.

Bell, B. D., 1996, Skill-biased technical change and wages: evidence from a longitudinal data set, Institute of Economics and Statistics, University of Oxford, mimeo.

Bellman, L. and T. Boeri, 1995, Internal and external creative destruction: determinants of changes of employment and productivity, Paper presented at the conference on the effects of technology and innovation on firm performance and employment, Washington DC.

Berman, E., J. Bound and Z. Griliches, 1994, Changes in the demand for skilled labor within US manufacturing: evidence from the annual survey of manufactures, Quarterly Journal of Economics, vol. CIX, no. 2, pp. 367-397.

Bound, J. and G. Johnson, 1992, Changes in the structure of wages in the 1980s: an evaluation of alternative explanations, American Economic Review, vol. 82, no. 2, pp. 371-392.

Chennels, L. and J. van Reenen, 1994, Investigating British skill differentials in the 1980s using individual establishment data, Institute for Fiscal Studies, London.

Cohn, E. and S. Kahn, 1995, The wage effect of overschooling revisited, Labour Economics, vol. 2, no. 1, pp. 66-76.

Colecchia, A. and G. Papaconstantinou, 1996, The Evolution of skills in OECD countries and the role of technology, STI Working Paper, 1996/8.

Denny, M. and M. Fuss, 1983, The effects of factor prices and technological change on the occupational demand for labour: evidence from Canadian telecommunications, The Journal of Human Resources, vol. XVII, no. 2, pp. 161-176.

Di Nardo, J. E. and J. S. Pischke, 1997, The returns to computer use revisited: have pencils changed the wage structure too?, Quarterly Journal of Economics, vol. 112, no. 1, pp. 291-303. 
Doms, M., T. Dunne and M. Roberts, 1997, Workers, wages and technology, Quarterly Journal of Economics, vol. 112, no. 1, pp. 253-290.

Entorf, H. and F. Kramarz, 1995, New technologies, wages and worker selection, Paper presented at the conference on the effects of technology and innovation on firm performance and employment, Washington DC.

European Union, 1997, Second European Report on S\&T Indicators (European Commission, Brussels).

Goldin, C. and L. F. Katz, 1998, The Origins of technology-skill complementarity, Quarterly Journal of Economics, vol. 113, no. 3, pp. 693-732.

Griliches, Z., 1969, Capital-skill complementarity, The Review of Economics and Statistics, vol. LI, no. 4, pp. 465-468.

Groot, W., 1993, Overeducation and the returns to enterprise-related schooling, Economics of Education Review, vol. 12, no. 2, pp. 21-40.

Hartog, J. and N. Jonker, 1996, A job to match your education: Does it matter? ROA, Maastricht.

Hartog, J. and H. Oosterbeek, 1988, Education, allocation and earnings in the Netherlands: Overschooling?, Economics of Education Review, vol. 7, no. 2, pp. 185-194.

Heckman, J., L. Lochner and C. Taber, 1998, Explaining rising wage inequality: explorations with a dynamic general equilibrium model of labor earnings with heterogenous agents, National Bureau of Economic Research, Working Paper No. 6384.

Heckman, J. and G. Sedlacek, 1985, Heterogeneity, aggregation and market wage functions: an empirical model of self-selection in the labor market, Journal of Political Economy, vol. 98, no. 4, pp. 1077-1125.

Hildreth, A., 1995, Rent-sharing and wages: product demand or technology driven premia?, Paper presented at the conference on the effects of technology and innovation on firm performance and employment, Washington DC.

Katz, L. and K. M. Murphy, 1992, Changes in relative wages, 1963-1987: supply and demand factors, Quarterly Journal of Economics, vol. 107, no. 1, pp. 35-78.

Krueger, A. B., 1993, How computers have changed the wage structure: evidence from micro data 1984-1989, Quarterly Journal of Economics, vol. CVIII, no. 1, pp. 33-60.

Laaksonen, S. and J. Vaniniomaki, 1995, The effects of advanced technologies and on wages and employment: experience from Finland using establishment panel and worker data, Paper presented at the conference on the effects of technology and innovation on firm performance and employment, Washington DC. 
Meghir, C. and E. Whitehouse, 1996, The evolution of wages in the United Kingdom: evidence from micro data, Journal of Labor Economics, vol. 14, no. 1, pp. 1-25.

Murphy, K. M., W. C. Riddell and P. M. Romer, 1998, Wages, skills and technology in the United States and Canada, in: E. Helpman, eds., General purpose technologies and economic growth (Cambridge MA: MIT Press).

Muysken, J. and B. Ter Weel (1998), Overeducation and crowdin out of low-skilled workers, in: Borghans, L. and A. de Grip, Skill utilisation and bumping down (London: Edward Elgar, forthcoming, 1999).

Nickell, S. J. and B. D. Bell, 1995, The collapse in demand for the unskilled and unemployment across the OECD, Oxford Review of Economic Policy, vol. 11, no. 1, pp. 40-62.

Petit, P. and L. Soete, 1998, Is a biased technological change fueling dualism, MERIT, mimeo.

OECD, 1994, The OECD Stan Database for Industrial Analysis (OECD, Paris).

OECD, 1996, Technology, productivity and job creation (OECD, Paris).

OECD, 1997a, Education at a glance (OECD, Paris).

OECD, 1997b, Employment outlook (OECD, Paris).

OECD, 1998a, Economic Surveys Netherlands (OECD, Paris).

OECD, 1998b, Employment outlook (OECD, Paris).

Oosterbeek, H. and D. Webbink, 1996, Over scholing, overscholing en inkomen, ESB, vol. 81, no. 4049 , pp. $240-241$.

Rumberger, R. W., 1986, The impact of surplus schooling on productivity and earnings, The Journal of Human Resources, vol. XXII, no. 1, pp. 24-50.

Sicherman, N., 1991, Overeducation in the labor market, Journal of Labour Economics, vol. 9, no. 2, pp. 101-122.

Wolff, E., 1995, Technology and the demand for skills, STI Review, no. 18. 